\title{
KINERJA WAKTU PROYEK PEMBANGUNAN GEDUNG KANTOR BUPATI TORAJA UTARA DI RANTEPAO
}

*)Yacob Bokko, Teknik Sipil Universitas Kristen Indonesia Toraja

${ }^{* *)}$ Harni Eirene Tarru, Teknik Sipil Universitas Kristen Indonesia Toraja

\section{Abstrak}

Proses perencanaan hingga pengendalian proyek selama pelaksanaan pekerjaan konstruksi merupakan kegiatan penting dari suatu proyek. Keberhasilan atau kegagalan dari suatu proyek dapat disebabkan perencanaan yang tidak matang serta pengendalian yang kurang efektif, sehingga kegiatan proyek tidak efisien. Hal tersebut akan mengakibatkan keterlambatan, menurunnya kualitas, dan meningkatnya biaya pelaksanaan.

Tujuan dari penulisan ini adalah untuk memberikan gambaran mengenai penerapan manajemen konstruksi berdasarkan jaringan kerja dengan metode Critical Path Method (CPM) dan Bar Chart yang dapat mengatur waktu penyelesaian proyek dengan lebih efisien dan efektif. Untuk dapat mengurangi dampak keterlambatan waktu proyek dapat diusulkanproses yang benar dengan alternatif pengendalian seperti; penambahan tenaga, kerja lembur, percepatan durasi dan monitoring.

Hasil data dilapangan dengan pemakaian tenaga kerja yang tersedia awal perencanaan proyek durasi penyelesaiannya adalah 218 hari. Sedangkan hasil perhitungan sesuai analisa SNI durasi penyelesaian pekerjaan menjadi 91 hari atau terjadi penghematan waktu 127 hari. Sehingga dapat dikatakan kinerja proyek tersebut mengalami keterlambatan.

Kata Kunci :Kinerja waktu, Manajemen Proyek, Metode CPM. 


\section{LATAR BELAKANG}

Secara umum defenisi dari manajemen proyek adalah merencanakan, mengorganisasi, memberi arah, dan mengendalikan sumber daya yang ada untuk jangka waktu, sasaran dan tujuan tertentu (Kerzner, 1995).

Saat ini banyak dijumpai proyek-proyek pembangunan gedung yang mempunyai performa yang kurang baik untuk penyelesaian tepat waktu, maka diperlukan suatu analisa kinerja tentang pelaksanaan manajemen waktu proyek gedung, sehingga dapat diketahui masalah-masalah yang dihadapi selama ini, yang nantinya dapat menjadi masukan bagi semua pihak, untuk dapat lebih baik lagi dalam pelaksanaan manajemen waktu suatu proyek bangunan gedung. Tujuan Penelitian ini adalah membuat perencanaan waktu proyek sebagai tolak ukur di dalam pelaksanaan, serta mengetahui kendala-kendala waktu pelaksanaan proyek gedung kantor Bupati Toraja Utara di Rantepao

\section{Metode Penelitian}

\subsection{Lokasi}

Lokasi daerah studi pembangunan Kantor Bupati di Rantepao Toraja Utara, dimana proyek tersebut terletak pada JIn. Ratulangi No. 72 Rantepao, dengan jumlah lantai bangunan Kantor Bupati adalah 2 (dua) lantai

\subsection{Ruang Lingkup Pekerjaan Proyek}

Adapun ruang lingkup pekerjaan proyek pembangunan gedung Kantor Bupati sementara adalah sebagai berikut:

A. Pekerjaan Lantai 1

Pekerjaan Persiapan, Pekerjaan Tanah, Pekerjaan Pondasi

untuk Pekerjaan pondasi harga satuan pekerjaan setiap $\mathrm{M}^{3}$ didasarkan pada volume yang dikerjakan oleh pelaksana dilokasi proyek.Dalam pekerjaan ini diawali dengan pemotongan besi beton, dibengkok dan dirakit, dalam pemotongan harus tepat untuk menghindari kelebihan potongan dan kekurangannya, ujung potongan besi dibengkok sesuai ukuran gambar rencana kemudian dirakit. 
Pekerjaan Beton, Pekerjaan Plesteran/Acian, Pekerjaan Pelapis Lantai seperti pasangan lantai keramik, Pekerjaan Pelapis Dinding, Pekerjaan kusen, pintu, jendela partisi, Pekerjaan Plafon, Pekerjaan Sanitair, Pekerjaan Perpipaan dan Pompa, Pekerjaan kaca dan Penggantung, Pekerjaan Pengecetan, Pekerjaan Listrik.

B. Pekerjaan Lantai 2 :

Pekerjaan Tanah, Pekerjaan Beton, Pekerjaan Dinding, Pekerjaan Plesteran/ Acian, Pekerjaan Pelapis lantai , Pekerjaan Pelapis Dinding, Pekerjaan Kusen, Pintu, Jendela Partisi, Pekerjaan Rangka dan Penutup Atap, Pekerjaan Plafond, Pekerjaan Sanitair, Pekerjaan Perpipaan dan Pompa, Pekerjaan Penutup Besi dan Baja, Pekerjaan Kaca dan Penggantung, Pekerjaan Pengecetan, Pekerjaan Listrik.

\subsection{Jangka Waktu Pelaksanaan}

Pada proyek ini, alat kendali waktu yang digunakan berupa Barchart (diagram balok), dimana pembagian komponen-komponen diambil secara garis besarnya saja.

\subsection{Uraian Jenis dan Volume Pekerjaan}

Sesuai dengan fungsinya, pada periode siklus proyek tertentu dibuat perkiraan biaya atau anggaran, yang dibagi ke dalam pekerjaan-pekerjaan yang lebih kecil, sebelum membuat perkiraan biaya, jadwal, dan anggaran, perlu diketahui terlebih dahulu defenisi lingkup proyek serta parameter yang membatasinya, hal ini merupakan penerapan dari stuktur pemecahan pekerjaan yang bertujuan agar pekerjaan lebih terkontrol.defenisi lingkup ini dihasilkan dari studi kelayakan yang kemudian lanjut pada tahap pengembangan dan perencanaan yang menjelaskan kapan biaya tersebut digunakan selama siklus proyek akan diperoleh anggaran (Iman Soeharto,2001).

\section{PEMBAHASAN}

\subsection{Data - data Proyek Pembangunan Gedung Kantor Bupati Toraja Utara di Rantepao}

Gambar Bangunan yang terdiri dari :

- Denah

- Tampak 
- Potongan

- Detail

Data data berupa : struktur kegiatan, rencana anggaran biaya, tenaga kerja

\subsection{Daftar Volume Pekerjaan}

Sebelum menghitung volume masing-masing pekerjaan, terlebih dahulu harus membaca gambar bestek gambar detail (penjelasannya). Penguasaan dalam membaca gambar bestek dan gambar penjelasan akan sangat mempengaruhi tingkat ketelitian dalam menghitung volume masing-masing pekerjaan. Tahapan yang perlu dilakukan dalam menghitung volume pekerjaan adalah menguraikan masing-masing volume pekerjaan (uraian volume pekerjaan) dan dari uraian tersebut masing-masing harus dihitung volume pekerjaanya. Adapun contoh volume pekerjaan sebagai berikut :

a. Volume pekerjaan pondasi batu kali $=60 \mathrm{m3}$, mempunyai pengertian bahwa, volume pekerjaan pondasi dihitung berdasarkan isi, yaitu panjang $\mathrm{x}$ luas penampang yang sama.

b. Volume pekerjaan atap $=124 \mathrm{~m} 2$, mempunyai pengertian bahwa, volume pekerjaan atap dihitung berdasarkan luas, yaitu luas bidang atap yang dapat berbentuk segitiga, persegipanjang, trapesium dan lain-lain.

c. Volume pekerjaan lisplank $=27 \mathrm{~m}$, volume pekerjaan lisplank dihitung berdasarkan panjang, atau pekerjaan lisplank dapat juga dihitung berdasarkan luas.

d. Volume pekerjaan besi $=258 \mathrm{~kg}$, volume pekerjaan besi dihitung berdasarkan berat dari besi, yaitu jumlah panjang tulangan dikalikan dengan berat jenis besi yang bersangkutan.

Dari contoh di atas dapat diketahui bahwa satuan masing-masing volume pekerjaan berbeda, volume pekerjaan pondasi $60 \mathrm{~m} 3$, volume pekerjaan atap $124 \mathrm{~m} 2$, volume pekerjaan lisplank $27 \mathrm{~m}$, volume pekerjaan besi $258 \mathrm{~kg}$, ini menunjukkan bahwa volume tersebut bukanlah volume dalam arti sesungguhnya 
melainkan volume dalam satu satuan.Volume pekerjaan tersebut dihitung berdasarkan pada gambar bestek dari bangunan yang akan dibuat. Semua bagian / elemen konstruksi yang ada pada gambar bestek harus dihitung secara lengkap dan teliti untuk mendapatkan perhitungan volume pekerjaan secara akurat dan lengkap.

\subsection{Perhitungan Durasi Pekerjaan}

Perhitungan durasi (Lamanya kegiatan) adalah sebagai berikut:

I. Pekerjaan Persiapan

1. Pengukuran dan Pemasangan Bowplank

$V=190,00 \mathrm{~m}^{\prime}$

Koefisien SNI

Pekerja $\quad=0,100$

Tukang Kayu $=0,100$

Kepala Tukang $=0,010$

Mandor $\quad=0,005$

$\Sigma$ Koefisien $=0,215$

Kap $=\frac{\sum \mathrm{I}}{\varepsilon \mathrm{K}}=\frac{1}{0,2}=79,07=79 \mathrm{OH}$

Durasi yang diperlukan untuk menyelesaikan pekerjaan adalah

Durasi $=\frac{\mathrm{V}_{\mathrm{i}} \mathrm{P} \mathrm{Pt}_{\mathrm{K}}}{\mathrm{K} \text {.T } \mathrm{K}}=\frac{1 . \mathrm{U}}{7}=2,4029=2 \mathrm{HO}$

II. Pekerjaan Tanah

1. Galian tanah sedalam $2 \mathrm{~m}$ (poer)

Volume $=137,89 \mathrm{m3}$

Koefisien SNI

Pekerja $\quad=0,6250$

Mandor $\quad=0,0450$ 


$$
\Sigma \text { Koefisien } \quad=0,6700
$$

$\mathrm{Kap}=\frac{\varepsilon \mathrm{T}}{\varepsilon \mathrm{K}}=\frac{2}{0,6}=37,313=37 \mathrm{OH}$

Durasi yang diperlukan untuk menyelesaikan pekerjaan adalah

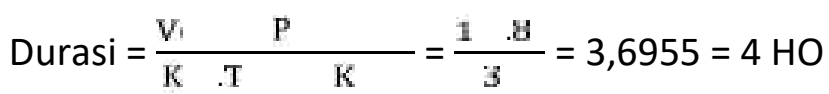

1. Pekerjaan Beton: Membuat sloof beton bertulang $20 \times 30$

Volume $=17,430 \mathrm{~m} 3$

Koefisien SNI

Pekerja $\quad=0.210$

Tukang batu $=0,350$

Tukang kayu $=1,560$

Tukang besi $=1,013$

Kepala Tukang $=0,323$

Mandor $=0,283$

$\varepsilon$ koef. $=3,739$

Kap $=\frac{\sum \mathrm{I}}{\sum \mathrm{K}}=\frac{2}{3,7}=5,6165=6 \mathrm{OH}$

Durasi yang diperlukan untuk menyelesaikan pekerjaan adalah

Durasi $=\frac{V_{1} \quad \mathrm{P}}{\mathrm{K} \text {.T }} \mathrm{K}=\frac{1,4}{6}=3,1034=3 \mathrm{HO}$

III. Pekerjaan Dinding

1. Pasang bata merah tebal $1 / 2$ bata $1 \mathrm{pc}: 4 \mathrm{psr}$

Volume $=949,00 \mathrm{~m} 2$

Koefisien SNI

Pekerja $\quad=0,120$

Tukang Batu $=0,080$ 
Kepala Tukang $=0,010$

Mandor $\quad=0,015$

Ekoefisien $\quad=0.225$

$\mathrm{Kap}=\frac{\sum \mathrm{I}}{\varepsilon \mathrm{K}}=\frac{3}{0,2}=155,56=156 \mathrm{OH}$

Durasi yang diperlukan untuk menyelesaikan pekerjaan adalah

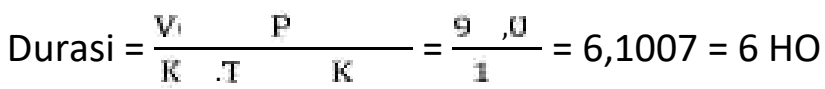

\subsection{Kesimpulan}

1. Dengan menggunakan analisis jaringan kerja dengan metode CPM dapat dilakukan upaya percepatan durasi proyek dengan mempercepat pekerjaan - pekerjaan yang berada pada lintasan kritis.

2. Data hasil proyek yang diperoleh durasi penyelesaiannya 218 hari, setelah melakukan analisa dengan Metode CPM sesuai analisa pekerjaan standar SNI durasi penyelesaian menjadi 91 hari.

3. Kinerja proyek tersebut lambat, yang di sebabkan seperti, faktor cuaca, lambatnya material yang masuk, dan adanya hari libur bagi tenaga, karena tenaga yang di pakai adalah tenaga yang di datangkan dari luar.

4. Untuk mengatasi perbedaan waktu antara penjadwalan menggunakan metode CPM dengan kenyataan pelaksanaan di lapangan perlu adanya penelitian lebih lanjut yang bisa mengakomodasi faktor kendala (keterlambatan material dan perubahan desain) di lapangan dengan memberikan faktor penyesuaian terhadap waktu yang direncanakan.

\subsection{Saran}

Berdasarkan kesimpulan diatas, dikemukakan beberapa saran yang dapat dijadikan sebagai bahan pertimbangan sebagai berikut:

1. Dalam membuat daftar rencana kegiatan sebaiknya dengan alat kendali berupa Network Diagram (jaringan kerja/CPM) dan Bar Chart (diagram 
balok) untuk menjadi acuan dalam analisa waktu, selain lebih mudah sudah banyak yang mengenal metode ini.

2. Penyusunan network diagram supaya penentuan lintasan kritisnya dapat optimal maka diperlukan penggunaan program Excel sebagai alat bantu dalam perhitungannya.

3. Dalam pengawasan dilapangan diperlukan perhatian yang lebih ketat pada kegiatan yang dianggap nantinya bisa mempengaruhi lamanya durasi pelaksanaan proyek.

4. Sebaiknya dalam perencanaan proyek terutama tenaga kerja perlu diperhitungkan secara matang agar hasil pelaksanaan proyek sesuai dengan schedule yang telah direncanakan.

5. Untuk penelitian selanjutnya sebaiknya diperluas lagi dengan menggunakan metode percepatan durasi proyek yang lain yang tidak digunakan dalam penelitian ini, sehingga dapat dijadikan bahan pembanding untuk mendapatkan kombinasi metode percepatan yang optimal.

\section{DAFTAR PUSTAKA}

Adhi Muhtadi, Jurnal Teknik Sipil, Neutron, vol.9, No.2:16-25, Agustus 2009. Abrar Husen, manajemen Proyek, Edisi 1, Yogyakarta, 2009.

Budi Santoso, Manajemen Proyek- Konsep dan Implementasi, Surabaya : Graha Ilmu 2008.

Erik W Larson, Manajemen Proyek, Edisi 3 Yogyakarta, 2007.

Gusti Ayu Mahanavami, jurnal, Perencanaan Waktu Pelaksanaan Proyek Gedung. H. B. Siswanto, Pengantar Manajemen, Penerbit PT Bumi Aksara Jakarta, 2005. H. Bachtiar Ibrahim, Rencana dan Estimate Real of Cost Cet. 7. Jakarta : Bumi Aksara, 2009. Imam Soeharto., Studi Kelayakan Proyek Industri , Penerbit ErlanggaJakarta, 2001.

Nurhayati, Manajemen Proyek, Edisi 1 Yogyakarta, Graha Ilmu, 2010.

Nila Ulvah, Neutron, Vol.9.1 Februari 2009, Jurnal

Sambodho Sumani, Ekonomi dan Manajemen Teknik, Edisi Kedua Yogyakarta : Graha IImu, 2009.

Wulfram I. Ervianto., Teori-Aplikasi Manajemen Proyek Konstruksi, penerbit Andi, Yogyakarta, 2004.

Wulfram I. Ervianto., Manajemen Proyek Konstruksi (Edisi Revisi), Penerbit Andi, Yogyakarta, 2002. 


\title{
Analisis Sifat Mekanis Komposit Resin Epoksi Serbuk Kayu Bayam
}

\author{
Frans R. Bethony, Dosen Jurusan Teknik Mesin Universitas Kristen Indonesia Toraja
}

\begin{abstract}
Abstrak
Penelitian ini bertujuan untuk mengetahui pengaruh fraksi berat komposit resin epoksi berpenguat serbuk kayu bayam terhadap tegagan tarik dan tegangan lentur. Dalam penelitian ini digunakan serbuk gergaji (sawdust) kayu bayam dengan ukuran $\leq 1-2 \mathrm{~mm}$. Persentase pencampuran resin - epoksi (matriks) dengan serbuk kayu bayam (filler/penguat) adalah sebesar 0\%, 5\%, $10 \%$, dan $15 \%$. Pengujian sifat mekanis pada pengujian ini adalah pengujian tegangan tarik/tensile test dan pengujian tegangan lentur/bending test.

Berdasarkan hasil penelitian ini didapatkan tegangan tarik tertinggi didapatkan pada fraksi berat $5 \%$ sebesar 22,56 $\left(\mathrm{N} / \mathrm{mm}^{2}\right)$ dan tegangan tarik terendah didapatkan pada fraksi berat $15 \%$ sebesar $6,41\left(\mathrm{~N} / \mathrm{mm}^{2}\right)$. Sedangkan tegangan lentur tertinggi didapatkan pada fraksi berat $5 \%$ sebesar 22,286 $\left(\mathrm{N} / \mathrm{mm}^{2}\right)$, dan tegangan lentur terendah didapatkan pada fraksi berat $15 \%$ sebesar 13,032 $\left(\mathrm{N} / \mathrm{mm}^{2}\right)$.
\end{abstract}

Kata kunci: resin - epoksi, serbuk kayu bayam, fraksi berat, tegangan tarik, tegangan lentur.

\section{A. Pendahuluan}

Serbuk sebagai elemen penguat sangat menentukan sifat mekanis dari komposit karena meneruskan beban yang didistribusikan oleh matriks. Orientasi ukuran dan bentuk serta material serbuk adalah faktor-faktor yang mempengaruhi properti mekanis dari komposit itu sendiri. Sebuk kayu yang dikombinasikan dengan resin sebagai matriks akan dapat menghasilkan komposit alternatif yang salah-satunya berguna untuk aplikasi material bodi bahan meubel. Dengan memvariasikan bentuk serbuk kontinu diharapkan didapatkan sifat-sifat mekanis komposit. Sifat-sifat mekanis yang didapatkan tentunya ada yang baik dan buruk sehingga dapat diketahui kelebihan dan kekurangan daripada penggunaan komposit serbuk kayu ini dengan perbandingan fraksi berat antara serbuk dengan resin.

Keunggulan komposit serbuk kayu dibandingkan dengan serat fiberglass adalah komposit serbuk kayu lebih ramah lingkungan karena mampu terdegradasi secara alami dan harganya pun lebih murah dibandingkan fiberglass. Sedangkan fiberglass sulit terurai secara alami. Selain itu fiberglass juga menghasilkan gas yang berbahaya bagi kesehatan jika fiberglass didaur ulang. Sehingga perlu adanya bahan alternatif pengganti fiberglass tersebut.

Dalam industri manufaktur dibutuhkan material yang memiliki sifat-sifat istimewa yang sulit didapat dari logam. Komposit merupakan material alternatif yang dapat digunakan untuk memenuhi kebutuhan tersebut. Material komposit 
adalah gabungan dari penguat dan matriks. Keunggulan material komposit jika dibandingkan dengan logam adalah perbandingan kekuatan terhadap berat yang tinggi, kekakuan, ketahanan terhadap korosi dan lain-lain.

Oleh karenanya, dewasa ini teknologi komposit mengalami kemajuan yang sangat pesat. Perkembangan komposit tidak hanya dari komposit sintetis tetapi juga mengarah ke komposit natural dikarenakan keistimewaan sifatnya yang renewable atau terbarukan, sehingga mengurangi konsumsi Petrokimia maupun gangguan lingkungan hidup.

Pengujian mengenai sifat mekanis komposit yang menggunakan serbuk sebagai bahan penguat komposit terhadap kekuatan komposit masih jarang dilakukan, untuk itu melalui penelitian ini kami mencoba meneliti sifat mekanis pada material komposit, akan tetapi penelitian kami masih terbatas pada sifat mekanis pada komposit serbuk kayu bayam - resin epoksi.

Penelitian ini diharapkan dapat digunakan sebagai referensi dalam menentukan tegagan tarik maupun kekuatan impak komposit khususnya komposit resin epoksi serbuk kayu bayam serta diharapkan dapat memberikan kontribusi terhadap perkembangan material alternatif yang lebih murah, berkualitas dalam proses produksinya.

\section{B. Teori Dasar}

Material komposit merupakan material yang terbentuk dari kombinasi antara dua atau lebih material pembentuknya melalui pencampuran yang tidak homogen, dimana sifat mekanis dari masing-masing material pembentuknya berbeda. Material komposit memiliki sifat mekanis yang lebih bagus dari pada logam, memiliki kekuatan bisa diatur yang tinggi (tailorability), memiliki kekuatan lelah (fatigue) yang baik, memiliki kekuatan jenis (strength/weight) dan kekakuan jenis (modulus Young/density) yang lebih tinggi daripada logam, tahan korosi, memiliki sifat isolator panas dan suara, serta dapat dijadikan sebagai penghambat listrik yang baik, dan dapat juga digunakan untuk menambal kerusakan akibat pembebanan dan korosi.

Secara umum material komposit tersusun dari dua komponen utama yaitu matrik (bahan pengikat) dan filler (bahan pengisi). Filler adalah bahan pengisi yang digunakan dalam pembuatan komposit, biasanya berupa serat atau serbuk. matrik dalam struktur komposit bisa berasal dari bahan polimer, logam, maupun keramik. Matrik secara umum berfungsi untuk mengikat serat menjadi satu struktur komposit

Sifat-sifat khas bahan industri perlu dikenal secara baik karena bahan tersebut dipergunakan untuk berbagai macam keperluan dalam berbagai keadaan. Sifat-sifat bahan yang diinginkan sangat banyak, termasuk: sifat-sifat mekanis (kekuatan, kekerasan, kekakuan, keliatan, keuletan, kepekaan takik atau kekuatan impak, ketahanan vibrasi dan sebagainya), sifat-sifat listrik (hantaran listrik dielektrisitas dan sebagainya), sifat-sifat magnet (permeabilitas, koersivitas, histrisis dan sebagainya), sifat-sifat kimia (reaksi kimia, kombinasi, segregasi, ketahanan korosi dan sebagainya), sifat-sifat fisik (ukuran, massa jenis, struktur dan sebagainya), sifat-sifat teknologi (mampu mesin, mampu keras dan sebagainya) dan masih banyak lainnya.

Kebanyakan

sifat-sifat 
tersebut ditentukan oleh jenis dan perbandingan atom yang membentuk bahan, yaitu unsur dan komposisinya. Sebagai contoh, kadar suatu unsur yang sangat rendah terabaikan dalam suatu ketakmurnian bahan memberikan pengaruh terhadap sifat-sifatnya, sifat-sifat mekanis yaitu kekuatannya demikian juga sifat ketahanan korosi termasuk reaksi kimianya, dipengaruhi oleh adanya sedikit ketakmurnian, inklusi atau cacat mikro.

\section{Bahan Komposit.}

Perkataan komposit memberikan suatu pengertian yang sangat luas dan berbeda-beda mengikuti situasi perkembangan bahan itu sendiri. Gabungan dua atau lebih bahan merupakan suatu konsep yang diperkenalkan untuk menerangkan definisi komposit. Struktur komposit menjanjikan keuntungan khusus, selain kekuatan, juga mempunyai nilai ekonomi dan ketahanan korosi. Sejarah perkembangan teknologi komposit mencatat berbagai temuan yang bersifat inovatif. Akhirnya pada skala yang lebih halus, kita mempertimbangkan penerapan prinsip komposit terhadap konstituan mikrostruktur (nanokomposit). Di sini digunakan model mekanisa yang relatif sederhana tetapi cukup memadai untuk memperkenalkan kaidah dasar untuk desain dan menjelaskan komposit (Smallman \& Bishop 2000). Dalam bidang rekayasa di mana kekuatan mekanis dan kekakuan merupakan persyaratan utama, istilah " komposit " dikaitkan dengan material yang mengkombinasi fasa matriks dengan campuran filamen yang berfungsi sebagai fasa penguat (penguatan). Komposit dikembangkan dari gagasan yang sederhana dan praktis di mana dua atau lebih material homogen dengan sifat yang sangat berbeda digabungkan.Keuntungan bahan komposit adalah mempunyai kualitas baik dengan sifat-sifat material yang diperbaiki sebagai berikut: Kekuatan, Konduktifitas panas, Kekakuan, Ketahanan Suhu, Kekuatan Fatik, Ketahanan aus, Berat, Ketahanan korosi.

Pada umumnya tidak semua sifat material di atas dapat dikembangkan pada waktu yang bersamaan pada satu bahan, tetapi disesuaikan dengan kondisi dan penggunaannya. Namun yang perlu diperhatikan pada komposit yang diperkuat agar dapat membentuk produk yang efektif adalah:

a. Komponen penguat harus memiliki modulus elastisitas yang lebih tinggi dari pada komponen matriksnya.

b. Harus ada ikatan permukaan yang kuat antara komponen penguat dengan matriksnya.

Seperti yang telah diketahui bahwa performa suatu bahan komposit ditentukan tidak hanya melalui sifat kimia secara konstituen tetapi juga melalui karakteristik geometriknya seperti diameter serbuk, bentuk dan orientasinya.

\section{Klasifikasi dan Karakteristik Bahan Komposit}

Secara umum komposit terdiri dari 4 jenis bahan yaitu :

\section{Fibrous composites .}

Merupakan jenis bahan komposit yang terdiri dari serat yang diletakkan dalam matriks sebagai pengikat. Contohnya; ban, selang air.

\section{Laminated composites .}


Merupakan jenis bahan komposit yang terdiri dari beberapa bahan yang disusun secara berlapis membentuk bahan baru.

3. Particulate composites .

Merupakan jenis bahan komposit yang terdiri dari partikel yang diikat oleh matriks sehingga membentuk bahan baru. Contohnya : untuk bahan non logam dalam matriks non logam yaitu semen + agregat, untuk bahan logam dalam bahan logam misalnya baja + aluminium, dan lain sebagainya.

4. Gabungan.

Merupakan jenis bahan komposit yang terdiri dari gabungan ketiga jenis komposit di atas. Contohnya beton bertulang.

\section{E. Komponen Komposit}

\section{a. Matriks}

Meskipun serbuk merupakan ciri khas komposit, pertama-tama kita memperhatikan fungsi matriks. Secara ideal, matriks seharusnya mampu untuk:

1. Menginfiltrasi serat atau partikel dan cepat membeku pada temperatur dan tekanan yang wajar.

2. Membentuk suatu ikatan yang koheren, umumnya dalam bentuk ikatan kimia di semua permukaan serat ( partikel ) / matriks.

3. Menyelubungi serat atau partikel yang biasanya sangat peka-takik, dan melindunginya dari kerusakan antar-serat berupa abrasi dan melindungi serat terhadap lingkungan.

4. Mentransfer tegangan kerja ke serat atau partikel.

5. Memisahkan ikatan dari serat / partikel individu dengan cara menyerap energi regangan, apabila kebetulan terjadi perambatan retak dalam matriks yang mengenai serat.

Untuk mendapatkan kemampuan yang tinggi dari suatu komposit, maka pemilihan bahan matriks yang sesuai sangat penting dan merupakan hal yang berpengaruh dari awal proses hingga menghasilkan suatu bahan polimer dengan beberapa sistem seperti linier, bercabang, dan hubungan silang /cross linkes . Sistem ini mewakili sifat/kemampuan sebagai penopang, pelindung serta pengikat.

Selain itu matriks juga berfungsi untuk melindungi serat atau partikel dan memberikan alat distribusi beban yang mentransmisikan beban / gaya diantara serat/partikel tersebut dapat membentuk komposit dengan kekuatan dalam arah, juga menghasilkan permukaan antara yang lemah dan untuk mengurangi kepekaan takik.

Secara khusus matriks mempunyai kekuatan, kekerasan, dan daya yang lebih rendah dari serat, ini baik untuk mengikat bekas serat yang kuat agar bila terjadi takik dan mengalami retakan, cukup terjadi di daerah dekat takik. Matriks pada umumnya terbuat dari bahan-bahan yang lunak dan liat. Polimer (plastik) merupakan bahan yang umum yang digunakan, meskipun dalam penggunaan yang memerlukan ketahanan temperatur yang tinggi. Beberapa material logam dapat digunakan seperti aluminium, tembaga, magnesium, bahkan titanium.

\section{b. Resin Epoksi}


Thermosetting plastik merupakan bahan plastik yang telah mengalami reaksi kimia oleh aksi panas atau katalis. Plastik ini tidak dapat dicairkan kembali dan diproses kembali jika dipanasi pada suhu tinggi akan terurai dan rusak, plastik termoset ini salah satunya adalah epoksi. Keuntungan plastik termoset ini dalam aplikasi perencanaan teknik adalah kekakuan tinggi, kestabilan suhu tinggi, kestabilan dimensi tinggi, resistensi terhadap mulur dan deformasi di bawah pembebanan, ringan dan sifat isolasi termal dan listrik yang tinggi.

Banyak jenis termoset plastik ini digunakan dalam bentuk cetakan terdiri dari dua kandungan utama : (1) resin mengandung zat pereaksi, hardener, dan plastisizer dan (2) pengisi atau pengisi resin/fenolik yang dapat berupa organik atau anorganik. Epoksi resin merupakan resin fenol yang umumnya diproduksi oleh reaksi fenol dan formaldehid dengan cara polimerisasi kondensasi dengan air menjadi produk. Jenis ini banyak digunakan karena murah dan sifat mekanisnya yang baik.

Beberapa tipe penggunaan adalah pelapisan tipe-tipe plywood dan partikel board. Sejenis resin fenolik ini digunakan juga untuk bahan pengikat untuk pasir dalam pengecoran/peleburan dan untuk dinding cetakan. Epoksi resin merupakan rumpun dari bahan polimer thermosetting yang tidak memberi produk reaksi saat hubungan silang (cross-link) sehingga mempunyai penyusutan rendah. Membentuk bahan termoset plastik yang solid dilakukan dengan mereaksikan dengan zat katalis untuk mendapatkan sifat yang diinginkan.

Plastik termoset tanpa penguat dikuatkan dengan adanya kreasi jaringan dari ikatan kovalen melalui keseluruhan struktur bahan. Jaringan kovalen ini dihasilkan dengan reaksi kimia dalam bahan termoset setelah di cor atau selama penekanan bawah panas dan tekanan. Karena jaringan ikatan kovalennya, bahan ini relatif tinggi modulus elastik dan kekakuannya sebagai bahan plastik.

Berat molekul yang rendah dari epoksi resin dalam keadaan cair memberikan mobilitas yang tinggi selama pengolahan. Sifat ini memberikan resin cair epoksi untuk membasahi keseluruhan permukaan dengan cepat. Aksi pembasahan ini penting untuk epoksi yang digunakan untuk bahan diperkuat dan adhesif, serta mampu tuang dan alir yang baik. Reaktivitas yang tinggi dengan zat reaktif ini memberikan kekerasan yang baik dan kekuatan serta resistensi kimia.

Aplikasi resin epoksi ini digunakan secara luas sebagai varietas pelapisan protektif dan dekoratif adhesif yang baik, kekuatan dan resistensi kimia yang baik. Penggunaan khusus biasa untuk otomotif, pelapisan kawat dan ketahanannya terhadap lingkungan basah atau kelembaban tinggi. Resin epoksi juga biasa digunakan untuk matriks penguat serat untuk komponen dengan performa tinggi seperti yang dilakukan dengan serat modulus tinggi.

Performa komposit ini ditentukan oleh sifat dan perilaku bahan yang membentuknya. Pembentuk dapat terdispersi dalam pola yang uniform untuk mendapatkan nilai sifat yang konstan, atau jika terdistribusi secara tak seragam dan tidak berulang maka sifat dapat bervariasi dari satu region ke region lain melalui penampang komposit.

\section{c. Partikel kayu (serbuk gergaji) Sebagai Penguat}


Menurut Strak \& Berger (1997) serbuk kayu memiliki kelebihan sebagai filler dibandingkan dengan filler mineral seperti mika, kalsium karbonat, dan talk yaitu:

1. Temperatur proses lebih rendah (kurang dari $400^{\mathrm{O}} \mathrm{F}$ ) dengan demikian mengurangi biaya energi.

2. Dapat terdegradasi secara alami.

3. Berat jenisnya jauh lebih rendah, sehingga biaya per volume lebih murah.

4. Gaya geseknya rendah sehingga tidak merusak peralatan pada proses pembuatan.

5. Berasal dari sumber yang dapat diperbarui.

Beberapa faktor yang perlu diperhatikan dalam pemanfaatan serbuk kayu sebagai filler dalam pembuatan komposit adalah jenis kayu, ukuran serbuk, fraksi volume / berat, dan kandungan air. Material kayu merupakan sumber daya alam yang dapat diperbaharui, dan tetap akan memegang peranan penting dalam material teknik pada umumnya. Oleh karena itu ketersediaan serbuk kayu gergaji akan tetap tersedia, jika kita ingin mengembangkan komposit partikel dalam penelitian ini.

\section{d. Sifat Mekanis}

Sifat mekanis suatu bahan meliputi : kekuatan, kekerasan, elastisitas, keuletan, ketangguhan. Setiap sifat mekanis dapat diuji dengan menggunakan peralatan mekanis dan dievaluasi untuk menentukan kegunaan material.

Adapun penjelasan mengenai sifat mekanis tersebut :

\section{Kekerasan}

Kekerasan dapat diidentifikasi sebagai ketahanan bahan terhadap penetrasi yang diberikan pada permukaannya. Besarnya harga kekerasan bahan dapat diketahui dengan melakukan pengujian kekerasan terhadap bahan yang bersangkutan. Kekerasan suatu bahan biasanya berhubungan dengan sifat-sifat mekanis lainnya, misalnya kekuatan. Dengan mengetahui nilai kekerasannya maka diperoleh gambaran tentang kekuatan dan proses-proses perlakuan yang mungkin telah dialami oleh bahan tersebut. Cara pengujian yang umum digunakan dalam industri adalah identiation hardness yang terdiri dari tiga jenis yaitu : metode Vickers, Brinel, dan Rockwell.

\section{Kekuatan}

Kekuatan bahan adalah besarnya gaya yang diberikan pada saat terjadi perpatahan. Kekuatan dari logam sering dianggap sama dan identik dengan tegangan, dimana kekuatan bahan dinyatakan dengan satuan gaya per satuan luas penampang dari bahan dan inilah yang disebut tegangan. Tegangan dari bahan dapat dibedakan atas tegangan tarik, tegangan geser, dan tegangan tekan.

Tegagan tarik merupakan salah satu sifat bahan yang dipergunakan untuk memperkirakan karakteristik bahan dalam perencanaan dan konstruksi. Tegagan tarik dapat ditentukan dengan pengujian tarik dimana sifat ini berbanding lurus 
dengan gaya yang diberikan dan berbanding terbalik dengan luas penampang mula-mula.

\section{Plastisitas}

Sifat plastisitas suatu bahan menunjukkan suatu keadaan dimana bahan tersebut jika dibebani akan terjadi deformasi yang tetap (permanen). Awal terjadinya deformasi yang ditandai dengan terjadinya pergeseran atom-atom atau molekul-molekul dalam bahan tersebut. Bahan logam yang mengalami deformasi plastis mempunyai kekuatan yang tinggi akibat distorsi yang terjadi, sehingga atom-atom semakin rapat.

\section{Keuletan.}

Keuletan suatu bahan yaitu sifat dimana bahan terdeformasi tetap pada waktu dibebani, walaupun beban tersebut ditiadakan. Ukuran keuletan bahan dapat diketahui dari uji tarik.

\section{Ketangguhan}

Ketangguhan suatu bahan yaitu kemampuan suatu bahan dalam menerima beban yang diberikan secara tiba-tiba. Ini dapat diketahui dengan melakukan pengujian impak.

\section{Pengujian Sifat Mekanis}

\section{Pengujian tarik/Tensile test}

Pengujian tarik biasanya dilakukan untuk melengkapi informasi rancangan dasar suatu bahan dari data pendukung bagi spesifikasi beban. Pada uji tarik, kedua ujung benda kerja di jepit dengan kuat dan salah satu ujungnya ditarik dengan beban sebesar P.

Regangan benda uji terlihat pada pergerakan relatifnya. Tegangan yang diperlukan untuk menghasilkan suatu regangan diukur dengan menggunakan metode hidraulik, elektro mekanis, dll. Tegagan tarik dapat diartikan sebagai ketahanan suatu bahan terhadap pengaruh beban yang memutuskan hubungannya. Untuk menentukan Tegangan pada uji tarik /Tensile test digunakan rumus sebagai berikut :

$$
\sigma=\frac{P}{A}\left(\mathrm{~N} / \mathrm{mm}^{2}\right)
$$

Dimana :

$\sigma=$ Tegangan Tarik $\left(\mathrm{N} / \mathrm{mm}^{2}\right)$

$P=$ Beban $(\mathrm{N})$

$A=$ Luas permukaan $\left(\mathrm{mm}^{2}\right)$

\section{Pengujian Lenturan/Bending Test}

Pengujian tegangan lentur/ bending dimaksudkan untuk mengetahui ketahanan komposit terhadap pembebanan titik lentur. Disamping itu pengujian ini bertujuan mengetahui keelastisitasan suatu bahan teknik. Pada pengujian ini terhadap sampel uji diberikan beban yang arahnya tegak lurus terhadap balok spesimen uji. 
$S=\frac{3 \times P \times L}{2 \times b \times a^{2}}$

Dimana :

$\mathrm{P}=$ Beban $(\mathrm{N})$

Lo = Jarak Tumpuan $(\mathrm{mm})$

$\mathrm{B}=$ Lebar spesimen $(\mathrm{mm})$

$\mathrm{d}=$ tebal spesimen $(\mathrm{mm})$

\section{F. HASIL DAN PEMBAHASAN}

a. Hasil Pengujian Tarik/Tensile test .

Pengujian tarik dilakukan untuk mengetahui tegangan tarik yang dialami oleh spesimen komposit serbuk kayu bayam - resin epoksi . Standar spesimen uji yang digunakan adalah Amerikan society For Testing and Materials (ASTM) D $638-02$.

Perhitungan data uji tarik maksimun pada spesimen Komposit serbuk kayu bayam dengan fraksi berat 5\% (spesimen 1) dengan gaya kontinyu $1700 \mathrm{~N}$.

Luas penampang $\mathrm{A}_{0}=\operatorname{Tebal}(\mathrm{T}) \times \operatorname{Lebar}(\mathrm{W})$

$=5 \mathrm{~mm} \times 13 \mathrm{~mm}=65 \mathrm{~mm}^{2}$

Tegangan Tarik Maksimum $\sigma=\frac{F}{A}\left(\mathrm{~N} / \mathrm{mm}^{2}\right)$

$=\frac{1700}{65}\left(\mathrm{~N} / \mathrm{mm}^{2}\right)=26,15384615\left(\mathrm{~N} / \mathrm{mm}^{2}\right)$

Perhitungan tegangan tarik maksimun pada spesimen Komposit serbuk kayu bayam dengan fraksi berat $5 \%$ ( spesimen 2 ) dengan gaya kontinyu $1750 \mathrm{~N}$.

Tegangan Tarik Maksimum $\sigma=\frac{F}{A}\left(\mathrm{~N} / \mathrm{mm}^{2}\right)$

$=\frac{1750}{65}\left(\mathrm{~N} / \mathrm{mm}^{2}\right)=26,9230769\left(\mathrm{~N} / \mathrm{mm}^{2}\right)$

Perhitungan tegangan tarik maksimun pada spesimen Komposit serbuk kayu bayam dengan fraksi berat $5 \%$ ( spesimen 3) dengan gaya kontinyu $950 \mathrm{~N}$.

Tegangan Tarik Maksimum :

$\sigma=\frac{F}{A}\left(\mathrm{~N} / \mathrm{mm}^{2}\right)=\frac{950}{65}\left(\mathrm{~N} / \mathrm{mm}^{2}\right)=14,61538462\left(\mathrm{~N} / \mathrm{mm}^{2}\right)$

\section{b. Perhitungan Uji Tarik}

Dari hasil Tabel perhitungan, maka didapatkan gambar Grafik Hubungan Fraksi Berat Material komposit Serbuk Kayu Bayam - Resin Epoksi dengan Tegangan Tarik, sebagai berikut : 


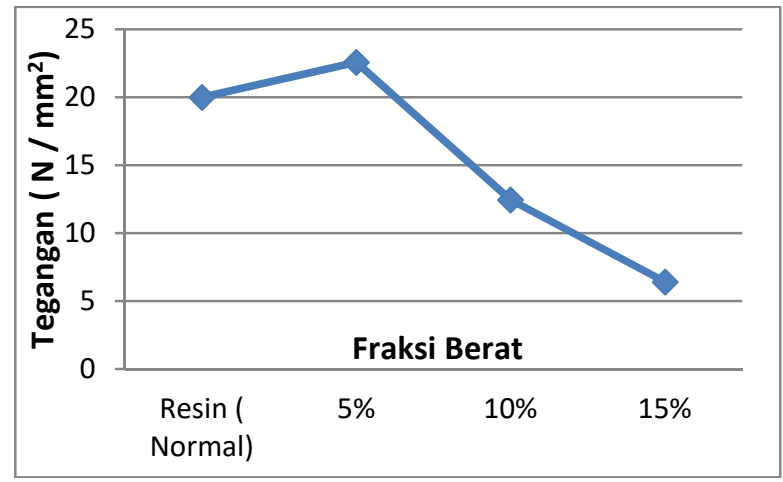

Grafik Fraksi Berat Terhadap Tegangan Tarik

\section{2 . Hasil pengujian lenturan / bending test .}

Standar Spesimen Uji Pengujian

Tarik berdasarkan American society For Testing and Materials ( ASTM ) 790M-84. Dari Hasil Pengujian Uji lentur yang dilakukan diperoleh :

a) Dimensi spesimen :

Panjang Tumpuan Spesimen Uji $(L) \quad=80 \mathrm{~mm}$

Lebar

$(b) \quad=27 \mathrm{~mm}$

Tebal

$(d)=18 \mathrm{~mm}$

Tegangan lentur/ bending Maksimum $S=\frac{3 \times P \times L}{2 \times b \times d^{2}}\left(\mathrm{~N} / \mathrm{mm}^{2}\right)$, dimana :

$$
\begin{aligned}
P & =\text { Beban } & (\text { Newton }) \\
L & =\text { panjang spesimen uji } & (\mathrm{mm}) \\
b & =\text { Lebar } & (\mathrm{mm}) \\
d & =\text { Tebal } & (\mathrm{mm})
\end{aligned}
$$

Perhitungan Tegangan lentur Pada komposit serbuk kayu bayam dengan fraksi berat $5 \%$ ( spesimen 1 ) dengan gaya kontinyu $2000 \mathrm{~N}$.

Tegangan Lentur Maksimum $\sigma=\frac{3 \times 2000 \times 80}{2 \times 27 \times 18^{2}}\left(\mathrm{~N} / \mathrm{mm}^{2}\right)$

$$
=\frac{480000}{17496}\left(\mathrm{~N} / \mathrm{mm}^{2}\right)=27,43 \quad\left(\mathrm{~N} / \mathrm{mm}^{2}\right)
$$

Perhitungan Tegangan lentur Pada komposit serbuk kayu bayam dengan fraksi berat $10 \%$ ( spesimen 2 ) dengan gaya kontinyu $1450 \mathrm{~N}$.

Tegangan Lentur Maksimum $=\frac{3 \times 1550 \times 80}{2 \times 27 \times 18^{2}}\left(\mathrm{~N} / \mathrm{mm}^{2}\right)$

$$
=\frac{372000}{17496}\left(\mathrm{~N} / \mathrm{mm}^{2}\right)=21,26 \quad\left(\mathrm{~N} / \mathrm{mm}^{2}\right)
$$


Perhitungan Tegangan lentur Pada komposit serbuk kayu bayam dengan fraksi berat $15 \%$ ( spesimen 3 ) dengan gaya kontinyu $1550 \mathrm{~N}$.

$$
\begin{aligned}
\text { Tegangan Lentur Maksimum } & =\frac{3 \times 1450 \times 80}{2 \times 27 \times 18^{2}}\left(\mathrm{~N} / \mathrm{mm}^{2}\right) \\
& =\frac{372000}{17496}\left(\mathrm{~N} / \mathrm{mm}^{2}\right) \\
& =19,89\left(\mathrm{~N} / \mathrm{mm}^{2}\right)
\end{aligned}
$$

Dari hasil perhitungan diatas maka didapat Tegangan Lentur Maksimum dan Tegangan Lentur Maksimum Rata - Rata dari masing - masing Spesimen di dalam tabel sebagai berikut :

Dari hasil Tabel perhitungan, maka didapatkan gambar Grafik Hubungan Fraksi Berat Material komposit Serbuk Kayu Bayam - Resin Epoksi dengan Tegangan Lentur Rata - rata, Sebagai berikut :

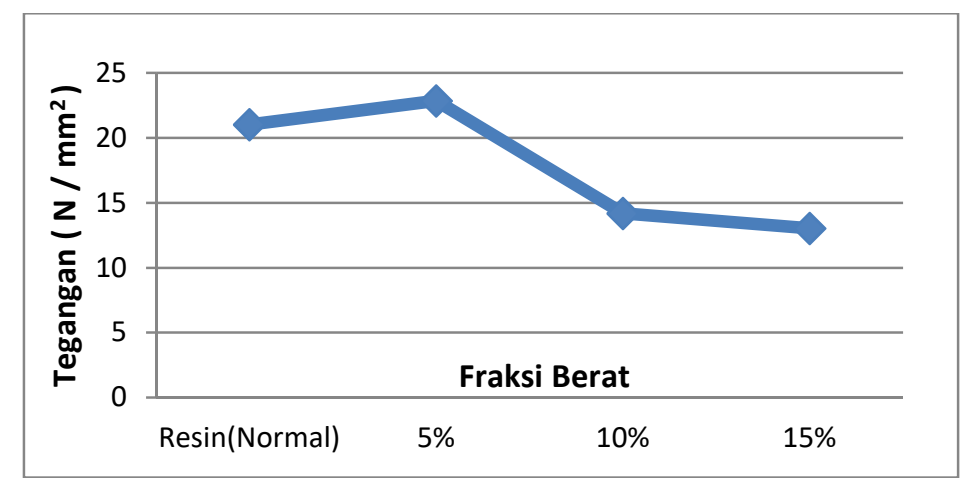

\section{Grafik Fraksi Berat Terhadap Tegangan Lentur}

\subsection{Pembahasan}

Berdasarkan hasil Penelitian pada material komposit serbuk kayu bayam dapat dilihat bahwa material komposit dengan $15 \%$ serbuk kayu bayam memiliki Tegangan Tarik paling rendah, kemudian mengalami kenaikan pada fraksi berat 5

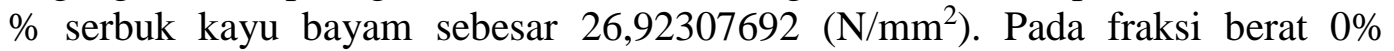
serbuk kayu bayam memiliki tegagan tarik rata - rata sebesar $20\left(\mathrm{~N} / \mathrm{mm}^{2}\right)$. Pada fraksi berat $10 \%$ serbuk kayu bayam memiliki tegagan tarik rata- rata sebesar $12,4358974\left(\mathrm{~N} / \mathrm{mm}^{2}\right)$.

Pada pengujian kelenturan, material komposit fraksi berat $15 \%$ serbuk kayu bayam memiliki tegangan lentur paling rendah, dan mengalami kenaikan tegangan lentur rata- rata pada fraksi berat 5\% serbuk kayu bayam sebesar 22,862 $\left(\mathrm{N} / \mathrm{mm}^{2}\right)$.Material komposit fraksi berat $0 \%$ serbuk kayu bayam mengalami tegangan lentur rata-rata sebesar 21,033 $\left(\mathrm{N} / \mathrm{mm}^{2}\right)$.

Pada fraksi berat $15 \%$ serbuk kayu bayam memiliki tegagan tarik paling rendah akibat jumlah filler yang lebih banyak, sehingga membuat distribusi antar partikel tidak saling mengikat dengan baik karena adanya kekosongan antar 
partikel untuk mengikat partikel filler. Pada fraksi berat $5 \%$ serbuk kayu bayam memiliki tegagan tarik terbaik. Dimana distribusi antar partikel serbuk kayu terjadi interaksi antara partikel dengan matriks, dimana distribusi partikel memegang peranan penting dalam interaksi ini, dengan adanya filler maka pada daerah polyethylene akan terisi oleh filler.

Mekanisme penguatan sangat di tentukan oleh ikatan antara permukaan filler dengan matriks. Apabila ikatan yang terjadi cukup kuat, maka mekanisme penguatan seperti tersebut diatas dapat terjadi. permukaan filler dan matriks yang terjadi, pada awalnya merupakan gaya adhesi yang bisa ditimbulkan karena :

a) Kekasaran bentuk permukaan yang dapat memungkinkan terjadinya interlocking antar muka partikel.

b) Adanya ikatan antar partikel karena adanya dipole antara filler dengan matriks.

Pada pengujian tarik yang telah dilakukan diperoleh hasil , bahwa persentase jumlah filler dalam komposit berpengaruh besar sekali terhadap tegagan tarik .

Pada material komposit serbuk kayu bayam dapat dilihat bahwa material komposit dengan fraksi berat $15 \%$ serbuk kayu bayam memiliki tegangan tarik paling rendah, kemudian mengalami kenaikan pada fraksi berat $5 \%$ serbuk kayu bayam sebesar 26,92307692 $\left(\mathrm{N} / \mathrm{mm}^{2}\right)$. Pada fraksi berat $0 \%$ serbuk kayu bayam memiliki tegagan tarik rata - rata sebesar $20\left(\mathrm{~N} / \mathrm{mm}^{2}\right)$. Pada fraksi berat $10 \%$ serbuk kayu bayam memiliki tegagan tarik rata- rata sebesar 12,4358974 $\left(\mathrm{N} / \mathrm{mm}^{2}\right)$.

Pada pengujian kelenturan, material komposit fraksi berat $15 \%$ serbuk kayu bayam memiliki tegangan lentur paling rendah,dan mengalami kenaikan tegangan lentur rata- rata pada fraksi berat 5\% serbuk kayu bayam sebesar 22,862 $\left(\mathrm{N} / \mathrm{mm}^{2}\right)$.Material komposit fraksi berat $0 \%$ serbuk kayu bayam mengalami tegangan lentur rata-rata sebesar $21,033\left(\mathrm{~N} / \mathrm{mm}^{2}\right)$. Dari Hasil pengujian, maka diperoleh Tegagan tarik Rata - rata dan Tegangan lentur Rata - rata tertinggi berada di Fraksi berat Komposit Serbuk Kayu $5 \%$.

\section{G. KESIMPULAN}

Berdasarkan hasil yang diperoleh dalam penelitian ini, maka dapat disimpulkan sebagai berikut :

1. Fraksi Berat berpengaruh terbalik terhadap Tegangan Tarik, dimana semakin besar Fraksi Berat, maka Tegangan Tarik semakin menurun. Tegangan Tarik tertinggi diperoleh pada Fraksi Berat 5\% sebesar 22,56 (N/mm²) .

2. Fraksi Berat berpengaruh terbalik terhadap Tegangan Lentur, dimana semakin besar Fraksi Berat maka Tegangan Lentur semakin menurun. Tegangan Lentur tertinggi diperoleh pada Fraksi Berat 5\% sebesar 22,862 $\left(\mathrm{N} / \mathrm{mm}^{2}\right)$. 


\section{DAFTAR PUSTAKA}

Amstead, B.H., Priambodo, Bambang. 1981. Teknologi Mekanis, (Terjemahan), Erlangga, Jakarta.

Gere, James M, Timoshenko, Bambang Suryoatmono. 2000. Mekanisa Bahan (Terjemahan). Penerbit Erlangga, Jakarta.

Jean-Marie Berthelot, J. Michael Cole. 1999. Composite Materials. SpringerVerlag New York, Inc.

Martawirya A, Kartasujana I, Kadir K, Prawira S A. 1989. Atlas Kayu Indonesia, Jilid I dan Jilid II. Departemen Kehutanan Badan Penelitian Dan Pengembangan Kehutanan, Bogor-Indonesia.

Robert M. Jones, 1975. Mechanics Of Composite materials , McGRAW- HILL, Kogakusha.

Surdia, Tata dan Saito, Shinroku. 1999. Pengetahuan Bahan Teknik, Pradnya Paramita, Jakarta.

Van Vlack Lawrence H, Djaprie Sriati. 1991. Ilmu dan Teknologi Bahan (Terjemahan), Erlangga, Jakarta. 